\section{AGRICULTURE, FISHERIES AND FOOD}

The Ministry of Agriculture, Fisheries and Food By Sir John Winnifrith. (The New Whitehall Series No. 11.) Pp. 271. (London: George Allen and Unwin, Ltd.; New York: Oxford University Press, Inc., 1962.) $30 s$.

1 HIS book is primarily meant for those interested in public administration. However, agriculture, fisheries and food attract attention from practically every branch of science, and mostly over the full range from fundamental research to simple applications to practice. Hence, readers of Nature will have special interest in the sections describing the scientific and technical activities, and the associated administrative procedures.

The book follows the general plan of the Series. The bulk of the text deals with the work of the Ministry; there are a compressed historical introduction and a concluding section describing the organization of headquarters, regional and local centres.

The story begins in 1793, when Sir John Sinclair and Arthur Young persuaded the Government to form an embryonic Board, which was passing rich on $£ 3,000$ a year, until they retired in 1820 , when first the grant, and later the Board, lapsed. Then followed fifty years of leisurely Government tinkering with problems like land tenure and cattle diseases, until 1889, when the Board of Agriculture was formed. It took over Fisheries from the Board of Trade in 1903, but parted with all its Scottish responsibilities to a newly formed Board there, in 1911. After the First World War the Board became a Ministry, through the curious procedural means of a private member's amendment to a Bill concerned mainly with other matters.

From 1930 onwards the work rapidly expanded: measures to cope with the slump in agricultural prices; import duties and quotas; marketing boards. The Second World War saw the immediate formation of a Ministry of Food, equipped with production plans, based on the experiences of 1914-18 and the inter-war years. The two Ministries achieved a remarkable and vital increase in home food produc. tion, both during and after the War. The present net output is 60 per cent above pre-war. Methods have been revolutionized: the high degree of mechanization on the land and in farm buildings is now common knowledge, but the fact that two-thirds of the calves born in England and Wales are conceived through artificial insemination may be less widely known.

Ultimately the future of the Ministry of Food had to be decided. The possibilities were abolition, continuation, dispersion into existing Government departments, or complete absorption into the Ministry of Agriculture and Fishories. The last of these was adopted after 'keen controversy'. Thus, the present-day Ministry, with its new unwieldy title, has grown from the $£ 3,000$ Sinclair-Young baby to a $£ 278$ million adult, and there is also a separately financed Scottish relative. But, of this large sum, nine-tenths is paid out in price guaranters, production grants and other subsidies.

A very summarized account is given of the sequence from 1910, when the Development Commission first made research grants under advice from the (then) Board of Agriculture, to the effectively independent present-day Agricultural Research Council, which dispenses yearly about $£ 6,500,000$ for fundamental research, mainly in the agriculture and veterinary sciences. Fishery research is still under the Ministry, and basic food research is mostly the concern of the Department of Scientific and Industrial Research, and various research associations. The Ministry now confines its attention to applied research, and the consequential control and advisory measures. It runs a number of laboratories, and a comprehensive National Agricultural Advisory Service, covering arable and animal husbandry. On the control side, special mention should be made of foot-and-mouth disease. The brief radio and Press announcements of an outbreak give no conception of the swift and intricate actions to contain it and to trace the precise origin of each fresh one. The account is aptly likened to thriller fiction and a Sherlock Holmes story-and it happens to be true.

Sir John Winnifrith, in his preface, pays tribute to his colleagues' efforts in assembling the data. He has been well briefed, but the information has obviously been sifted and assembled through one mind. The result is a very readable and informative book, with oceasional neat touches of humour to please the attontive reader.

B. A. Kren

\section{PLANT SURVIVAL THROUGH THE RUSSIAN WINTER}

\section{Wintering of Plants}

By I. M. Vasil'yev. Translated from the Russian by Royer and Roger, Inc. Editor of English translation: Jacob Levitt. Pp. xiv +300 . (Washington, D.C.: American Institute of Biological Sciences, 1961.) 9 dollars.

T a country the size of the U.S.S.R., where even in the warmest latitudes temperatures may drop below $-4^{\circ} \mathrm{C}$, great importance is attached to research on wintering of plants. Unfortunately it has always been difficult for Western scientists to obtain more than a fragmentary record of this work since there has been no review of the subject translated into English. The American Institute of Biological Science has now provided such a review, originally published in the U.S.S.R. in 1956, which it has made the first of a series of translations of major Russian works in biology. The book aims to be of practical value, so it should have a wide appeal to those interested in either pure or applied botany.

The injurious effects and the causes of death due to cold, including chilling injury to half-hardy plants, are considered first. Apart from the inherent hardiness of the plants, the importance of good agronomic practice, both in land preparation and in subsequent husbandry, is emphasized. Snow is of major importance as an insulator from extremes of cold. As it is of limited value in protecting trees, various other methods of protection are described, ranging from the ingenious to the drastic.

The second and largest part of the book is devoted to the physiological aspects of wintering, and in it Vasil'yev describes many of his own experiments. The ability of a cell to survive at low temperatures rests on whe adaptability of its protoplasm to the increasing cold at the onset of winter. The active changes involved in the protoplasm give it properties similar to those in young cells, and so hardening is 